E-JURNAL EKONOMI DAN BISNIS UNIVERSITAS UDAYANA
Available online at https://ojs.unud.ac.id/index.php/EEB/index
Vol. 10 No. 8 August 2021, pages: 656-663
e-ISSN: 2337-3067

\title{
KONSEP SISTEM EKONOMI KERAKYATAN DALAM PEMBERDAYAAN UMKM INDONESIA
}

\section{Farida Styaningrum ${ }^{1}$}

\begin{tabular}{|c|c|}
\hline Article history: & Abstract \\
\hline $\begin{array}{l}\text { Submitted: } 18 \text { Januari } 2021 \\
\text { Revised: } 6 \text { Mei } 2021 \\
\text { Accepted: } 23 \text { Mei } 2021\end{array}$ & $\begin{array}{l}\text { The populist economic system which is based on kinship, } \\
\text { democracy and justice encourages the Indonesian people to participate in } \\
\text { capital ownership. Small and Medium Enterprises (SMEs'), which majority } \\
\text { ownership of capital by local communities can be evidence of the } \\
\text { application of the populist economy system in Indonesia. The study } \\
\text { objective focuses on the concept of a populist economy svstem in }\end{array}$ \\
\hline $\begin{array}{l}\text { Keywords: } \\
\text { Populist economic system; } \\
\text { Empowerment of SMEs'; } \\
\text { National economy; }\end{array}$ & $\begin{array}{l}\text { empowering SMEs' in Indonesia. The study method is literature study with } \\
\text { secondary data in the form of scientific articles and regulations that act as } \\
\text { data sources. The results of the analysis show that in the current era of } \\
\text { regional autonomy, the populist economy system for empowering SMEs' } \\
\text { can be realized by raising local potential in order to increase regional } \\
\text { economic independence. Empowerment of SMEs' based on a populist } \\
\text { economy system must be a priority in enhancing national development, } \\
\text { because it is proven that the SMEs' sector is able to withstand any climate } \\
\text { change, including in crisis conditions. With the foundation of the spirit of } \\
\text { the populist economy system ideology from interested parties, SMEs' can } \\
\text { develop and improve Indonesia's national economy. }\end{array}$ \\
\hline
\end{tabular}

\section{Kata Kunci:}

Sistem ekonomi kerakyatan; Pemberdayaan UMKM; Perekonomian nasional

\section{Koresponding: \\ Universitas PGRI Madiun, Jawa Timur, Indonesia Email: faridastyaningrum@unipma.ac id}

\section{Abstrak}

Sistem Ekonomi Kerakyatan yang berasaskan pada kekeluargaan, demokratis dan berkeadilan mendorong rakyat Indonesia untuk ikut serta dalam kepemilikan modal. Usaha mikro, kecil, dan menengah (UMKM) yang mayoritas kepemilikan modal oleh masyarakat daerah dapat menjadi bukti berlakunya sistem Ekonomi Kerakyatan di Indonesia. Tujauan penelitian terfokus pada konsep sistem Ekonomi Kerakyatan dalam pemberdayaan UMKM di Indonesia. Metode penelitian yaitu studi literatur dengan data sekunder berupa artikel-artikel ilmiah dan peraturan yang berlaku sebagai sumber data. Hasil analisis menunjukkan bahwa dalam era otonomi daerah saat ini, sistem Ekonomi Kerakyatan untuk pemberdayaan UMKM dapat diwujudkan dengan mengangkat potensi lokal agar dapat meningkatkan kemandirian ekonomi daerah. Pemberdayaan UMKM yang berdasar pada sistem Ekonomi Kerakyatan sudah harus menjadi prioritas dalam meningkatkan pembangunan nasional, karena terbukti sektor UMKM mampu bertahan pada setiap perubahan iklim ekonomi termasuk dalam kondisi krisis. Dengan landasan semangat ideologi sistem Ekonomi Kerakyatan dari pihak-pihak berkepentingan, maka UMKM dapat berkembang dan meningkatkan perekonomian nasional Indonesia. 


\section{PENDAHULUAN}

Sistem ekonomi merupakan seperangkat komponen yang disusun secara sistematis untuk mengatur seluruh kegiatan ekonomi masyarakat dengan tujuan mencapai kesejahteraan. Menurut Bhudianto (2012) sistem ekonomi adalah sistem sosial kemasyarakatan yang bertujuan untuk mencapai kemakmuran. Suatu negera memberlakukan suatu sistem ekonomi didasarkan pada prinsipprinsip yang dianut sehingga bersifat khas dan menjadi pembeda dengan sistem ekonomi negara lain. Negara Indonesia saat ini menganut sistem Ekonomi Kerakyatan yang bermoral Pancasila, berasas pada kekeluargaan, berkedaulatan pada rakyat dan sungguh-sungguh berpihak pada rakyat (Mubyarto, 2014).

Ekonomi Kerakyatan Indonesia saat ini merupakan sub-sistem dari Ekonomi Pancasila. Pada sistem Ekonomi Pancasila menekankan pada lima sila yaitu bermoral, manusiawi, nasionalis, demokratis dan berkeadilan, maka sistem Ekonomi Kerakyatan lebih menekankan pada sila keempat yaitu demoktaris (Mubyarto, 2014). Pancasila sebagai paradigma pembangunan ekonomi nasional bermaksud bahwa setiap pembangunan dalam sektor ekonomi harus berdasarkan pada nilai yang terdapat dalam kelima sila Pancasila, yaitu dengan mengembangkan demokrasi ekonomi yang berkeadilan dan bertujuan untuk memeratakan kesejahteraan rakyat Indonesia secara keseluruhan (Malau, 2016). Sistem Ekonomi Kerakyatan berasaskan pada kekeluargaan, demokratis dan berkeadilan mendorong rakyat Indonesia untuk ikut serta dalam kepemilikan modal dan sebagai pengendali perekonomian.

Strategi pembangunan nasional dengan memberdayakan rakyat dalam melaksanakan demokrasi ekonomi, yaitu melibatkan rakyat dalam setiap kegiatan ekonomi. Atas kepemilikan rakyat maka rakyatlah yang melakukan kegiatan ekonomi dan akan kembali ke rakyat. Mengutamakan kemakmuran dan kesejahteraan rakyat daripada orang pribadi atau golongan tertentu. Sistem ekonomi yang berkeadilan sosial mewujudkan kemandirian ekonomi, berdaulat politik, serta berbudaya. Dalam sektor ekonomi, penerapan sistem Ekonomi Kerakyatan memberikan kontribusi sangat besar terhadap kehidupan ekonomi masyarakat, baik secara nasional maupun daerah.

Sistem Ekonomi Kerakyatan merupakan wujud dari perekonomian yang berbasis rakyat yaitu perekonomian yang fokus pada kepentingan rakyat dan merupakan inti dari Pasal 33 UUD 1945 (Swasono, 2020). Dalam Pasal 33 menunjukkan bahwa yang mendasari demokrasi ekonomi adalah keutamaan dalam mewujudkan kemakmuran dan kesejahteraan rakyat umum, bukan kemakmuran dan kesejahteraan orang pribadi atau golongan tertentu. Makna yang terkandung dalam Pasal 33 dapat disimpulkan jika prinsip dari sistem Ekonomi Kerakyatan yaitu adanya larangan untuk perorangan atau pihak-pihak tertentu dalam menguasai sumber daya alam secara penuh, sehingga menimbulkan praktek kartel, oligopoli, maupun monopoli dalam kegiatan pemanfaatan sumber daya alam.

Dalam Pasal 33 juga dijelaskan jika penopang perekonomian Indonesia adalah koperasi, badan usaha atau organisasi negara, badan usaha atau organisasi daerah, dan badan usaha atau organisasi swasta yang akan merealisasikan demokrasi ekonomi yang memiliki ciri yaitu berdasarkan pada mekanisme pasar, adanya intervensi dari pemerintah pusat, serta hak milik perseorangan diakui. Penjelasan kalimat dalam Pasal 33 UUD 1945 ayat (2) dan (3) yaitu "dikuasai oleh negara" bukan berarti berupa kepemilikan oleh negara namun peran negara dalam melakukan kontrol, pengaturan, pengawasan serta membuat kebijakan agar pelaku usaha tetap berpegang pada asas keadilan sosial yang mengutamakan kepentingan masyarakat keseluruhan untuk meningkatkan kemakmuran dan kesejahteraan masyarakat. 
Konsep dari sistem Ekonomi Kerakyatan berbasis pada kedaulatan rakyat yaitu kekuatan ekonomi yang ada di tangan rakyat. Dalam prinsip demokrasi ekonomi, dapat diartikan bahwa tidak semua dikuasai rakyat tetapi pemerintah juga memiliki kewenangan terkait penyusunan kebijakankebijakan ekonomi dengan tujuan untuk mewujudkan keadilan sosial melalui pemberdayaan masyarakat (Firmansyah, 2012).

Kegiatan pemberdayaan masyarakat dalam sektor ekonomi dapat dilakukan melalui upaya memberdayakan Usaha Mikro, Kecil dan Menengah (UMKM) yang berada pada daerah-daerah Negara Indonesia. Sektor UMKM merupakan wujud dari sistem Ekonomi Kerakyatan yang mampu menjalankan prinsip-prinsip sistem Ekonomi Kerakyatan dalam kegiatan ekonominya. Mayoritas UMKM mengelola sumber daya alam lokal yang potensial untuk kemakmuran dan kesejahteraan masyarakat. Penelitian ini terfokus pada konsep sistem Ekonomi Kerakyatan dalam pemberdayaan UMKM Indonesia. Dengan memperhatikan kegiatan ekonomi para pengusaha UMKM maka pemahaman mengenai konsep sistem Ekonomi Kerakyatan mulai dijalankan, sehingga pengusaha UMKM akan lebih maju dan berkembang dan memberi kontribusi pada peningkatan perekonomian nasional.

\section{METODE PENELITIAN}

Penelitian yang dilakukan masuk dalam ketegori jenis penelitian kualitatif dengan metode studi literatur. Tujuan penelitian adalah memberikan sumbangan pemikiran terkait konsep sistem Ekonomi Kerakyatan dalam pemberdayaan UMKM di Indonesia. Harapannya pemerintah dan pihakpihak terkait lebih memperhatikan sektor UMKM dengan menerapkan prinsip-prinsip sistem Ekonomi Kerakyatan untuk mancapai keadilan sosial dan kesejahteraan masyarakat Indonesia. Data penelitian bersumber dari data sekunder yang dikumpulkan dari berbagai dokumen berupa peraturan perundangundangan, artikel dan buku yang relevan dengan fokus dan tujuan penelitian. Validasi data menggunakan teknik triangulasi teori yaitu menganalisis informasi-informasi dari berbagai sumber teori yang sama untuk mendapatkan informasi yang lebih jelas, akurat, relevan dan valid (Thurmond, 2001). Data yang relevan dan valid kemudian dianalisis dan dibahas secara mendalam untuk memperoleh kesimpulan penelitian yang kredibel. Hasil penelitian akan digunakan sebagai bahan pertimbangan untuk menyusun strategi pemberdayaan UMKM yang sesuai dengan sistem perekonomian yang berlaku di Negara Indonesia yaitu Ekonomi Kerakyatan.

\section{HASIL DAN PEMBAHASAN}

Di Indonesia, sistem perekonomian Kerakyatan mulai diterapkan ketika adanya era Reformasi di tahun 1998. Pemerintah pusat melalui ketetapan Majelis Permusyawaratan Rakyat (MPR) Republik Indonesia Nomor IV/MPR/1999 tentang Garis-Garis Besar Haluan Negara (GBHN) menyatakan bahwa sistem Ekonomi Kerakyatan sebagai sistem perekonomian Indonesia. Penerapan dari sistem Ekonomi Kerakyatan bertujuan meningkatkan kemakmuran dan kesejahteraan ekonomi masyarakat secara keseluruhan dengan aktif mengikutsertakan seluruh masyarakat dalam proses pembangunan nasional yang demokratis, berpihak pada rakyat dan berkeadilan sosial bagi seluruh masyarakat (Suryati \& Salkiah, 2019).

Dikembangkannya sistem Ekonomi Kerakyatan di Indonesia sebagai upaya untuk lebih memprioritaskan kepentingan masyarakat. Konsep sistem Ekonomi Kerakyatan diterapkan sebagai 
sebuah langkah upaya strategi untuk mewujudkan keadilan dan kesejahteraan dalam sektor ekonomi melalui pemberdayaan masyarakat. Tujuan yang paling mendasar dalam penerapan sistem Ekonomi Kerakyatan adalah untuk merealisasikan prinsip demokrasi dan prinsip keadilan melalui peningkatan peran masyarakat dalam pengaturan dan pengendalian arah laju ekonomi nasional (Hapsari, 2019; Marzuki, 2015).

Pada sistem Ekonomi Kerakyatan, masyarakat berperan penting untuk ikut aktif berperan dalam setiap kegiatan di sektor ekonomi, sedangkan pemerintah berperan dalam membentuk iklim ekonomi yang demokratis dan adil bagi perkembangan dan keberlanjutan dunia industri dan usaha. Sistem Ekonomi Kerakyatan di Indonesia yang didasarkan pada Pasal 33 UUD 1945 dan berlandas pada keadilan sosial, menyatakan bahwa semua sumber daya di Indonesia di bawah penguasaaan negara dan digunakan untuk kepentingan masyarakat umum (seperti penguasaan sumber daya alam). Pengertian "dikuasai oleh negara" bermakna bahwa segala sumber kekayaan alam seperti bumi, air dan kekayaan alam yang terdapat di dalamnya digunakan secara optimal dam maksimal untuk kemakmuran dan kesejahteraan rakyat. Kebijakan pemerintah dibutuhkan dalam kegiatan pengurusan, pengaturan, pengelolaan, dan pengawasan penggunaan sumber kekayaan alam di Indonesia.

Prinsip dasar Ekonomi Kerakyatan yang berdasar pada Pasal 33 UUD RI tahun 1945 yaitu: (1) asas kekeluargaan menjadi dasar perekonomian, (2) negara menguasai cabang produksi yang memenuhi kebutuhan rakyat banyak, (3) kekayaan sumber daya alam oleh negara dikuasai dan dimanfaatkan sungguh-sungguh bagi kemakmuran dan kesejahteraan rakyat Indonesia, dan (4) perekonomian didasarkam pada demokrasi ekonomi. Keempat prinsip tersebut menunjukkan bahwa perekonomian Indonesia harus dijalankan secara bersama dan dengan semangat kerja sama antara pemerintah serta masyarakat dalam memberdayakan pelaku ekonomi secara adil sehingga terwujud sistem Ekonomi Kerakyatan yang sesuai dengan UUD 1945 Pasal 33.

Menurut Hapsari (2019) prinsip dasar Ekonomi Kerakyatan secara yuridis dalam Pasal 33 UUD 1945 adalah (1) prinsip kekeluargaan, digunakan sebagai pedoman dalam melaksanakan usaha oleh perusahaan milik negara, milik daerah ataupun milik swasta. Koperasi menerapkan prinsip kekeluargaan. (2) Prinsip keadilan, digunakan untuk memberikan keadilan kepada semua masyarakat dalam melaksanakan kegiatan ekonomi. (3) Prinsip pemerataan pendapatan, digunakan sebagai upaya dalam menumbuhkan dan mengembangkan ekonomi dengan tidak terjadinya ketimpangan pendapatan yang besar dalam masyarakat. (4) Prinsip keseimbangan yaitu adanya kesamaan perlakuan antara kepentingan yang bersifat pribadi dan yang menyangkut kepentingan masyarakat. Kepentingan individu tetap diperhatikan dengan tidak mengabaikan kepentingan masyarakat. (5) Prinsip kerja sama atau jaringan, digunakan agar terjadi hubungan kerja sama yang baik antarpelaku ekonomi untuk memperkuat perekonomian.

Menurut Marzuki (2015), Ekonomi Kerakyatan merupakan sistem perekonomian yang berdasar pada kedaulatan rakyat. Keikutsertaan rakyat dalam segala aktivitas ekonomi akan mewujudkan kemakmuran dan kesejahteraan ekonomi masyarakat. Masyarakat yang melaksanakan kegiatan ekonomi berlandaskan sistem Ekonomi Kerakyatan yaitu dengan mengelola sumber daya ekonomi yang terdapat di lingkungan sekitar secara bijak dengan pengetahuan dan keterampilan yang dimiliki. Kegiatan ekonomi masyarakat dilakukan dengan mengandalkan kekuatan yang dimiliki untuk mengelola sumber daya yang ada disekitar dan dalam penguasaanya. Kegiatan ekonomi yang dilakukan masyarakat dengan mengimplementasikan sistem Ekonomi Kerakyatan dapat direalisasikan dalam sektor Usaha Mikro, Kecil dan Menengan (UMKM). Kebanyakan UMKM mengolah sumber daya lokal yang ada di lingkungan sekitar dengan memberdayakan masyarakat sekitar untuk mencapai kemakmuran dan kesejahteraan bersama.

Konsep Sistem Ekonomi Kerakyatan Dalam Pemberdayaan UMKM Indonesia Farida Styaningrum 
UMKM memiliki daya saing yang tinggi yaitu bersifat fleksibel dan memiliki produktivitas tinggi. UMKM mampu mengelola usaha dengan menerapkan prinsip-prinsip dalam sistem Ekonomi Kerakyatan untuk mencapai kedaulatan rakyat dalam sektor ekonomi sesuai dengan Pasal 33 UUD RI tahun 1945 (Kader, 2018). Kebijakan pembangunan ekonomi kerakyatan yang didukung dengan adanya peraturan dan perundang-undangan yang berlaku akan mampu mengembangkan sektor UMKM dalam upaya mewujudkan keadilan dan kesejahteraan rakyat (Hoesein, 2016).

Ditetapkannya Undang - Undang Nomor 32 Tahun 2004 tentang otonomi pemerintah daerah, menyebabkan terjadinya perubahan arah pembangunan ekonomi yang awalnya bersifat sentralisasi, menjadi bersifat desentralisasi yaitu memberi kewenangan kepada tiap-tiap daerah dalam pengambilan keputusan untuk pembangunan wilayahnya termasuk dalam pembangunan ekonomi. Penerapan sistem Ekonomi Kerakyatan yang didasarkan pada aturan otonomi daerah yang desentralisasi terkait pemanfaatan sumber daya ekonomi yang demokratis, berkeadilan sosial dan berasaskan kekeluargaan maka dapat memberdayakan masyarakat daerah serta meningkatkan pembangunan ekonomi daerah secara mandiri sesuai dengan sumber daya yang dimiliki.

Pembangunan ekonomi daerah merupakan bentuk kerja sama antara pemerintah daerah, masyarakat, maupuan pihak swasta dalam pemanfaatan dan pengelolaan sumber daya ekonomi daerah sebagai upaya untuk mengangkat potensi daerah, menciptakan lapangan kerja dan meningkatkan perekonomian daerah. Implementasi pembangunan ekonomi daerah dapat terwujud dengan pemberdayaan Usaha Mikro, Kecil, dan Menengan (UMKM) yang memanfaatkan potensi sumber daya ekonomi daerah untuk bersaing di sektor usaha. Dalam pemberdayaan UMKM, perlu memperhatikan aspek sosial dan budaya di masing-masing daerah karena UMKM tumbuh dan berkembang dari dukungan masyarakat sekitar (Retnowati, Boediningsih, \& Afdol, 2018).

Permasalahan dalam pembangunan ekonomi daerah adalah terjadinya ketimpangan dalam pembangunan ekonomi, investasi tidak merata, rendahnya mobilitas faktor produksi, sumber daya alam yang berbeda di setiap daerah, demografi yang berbeda dan perdagangan antardaerah kurang berjalan lancar (Bhudianto, 2012). Menurut Sadikin (2011) pemerintah belum fokus dalam pembangunan ekonomi rakyat di sektor UMKM sehingga swadaya masyarakat belum terealisasi. Terbukti masih kurangnya program promosi untuk produk UMKM, pengetahuan dan keterampilan sumber daya manusia yang masih rendah, pengembangan teknologi yang lambat serta kurangnya dukungan pada akses permodalan. Permasalahan tersebut dapat diminimalisir apabila beberapa pihak seperti pemerintah, masyarakat, stakeholder, dan pihak swasta saling bekerja sama yang dilandasi dengan semangat dalam mewujudkan sistem Ekonomi Kerakyatan dan semangat kebersamaan mengembangkan dan memajukan pembangunan ekonomi daerah (Santosa, 2020).

Pemerintah daerah tidak dapat secara maksimal melaksanakan kebijakan pembangunan ekonomi daerah tanpa peran pengusaha UMKM yang ikut serta membantu menyelesaikan dengan didukung adanya pelaksanaan otonomi daerah yang berlandasakan sistem Ekonomi Kerakyatan. Regulasi yang baik berupa undang-undang dan peraturan pemerintah terkait dengan UMKM akan mendorong peranan UMKM dalam peningkatan perekonomian daerah (Retnowati et al., 2018). Kebijakan pemerintah daerah memiliki kekuatan yang besar terhadap pelaksanaan program pemberdayaan UMKM untuk mencapai kesejahteraan masyarakat secara luas.

UMKM merupakan usaha ekonomi produktif yang dikelola dan dikembangkan oleh badan usaha atau perorangan dengan tujuan membangun perekonomian nasional yang didasarkan pada rikeadilan dan berasas demokrasi ekonomi. Data yang bersumber dari Badan Pusat Statistik (BPS) menunjukkan bahwa dampak terjadi krisis ekonomi yang berlangsung di Indonesia selama tahun 1997-1998, adanya peningkatan jumlah UMKM, bahkan sampai tahun 2012 UMKM menunjukkan 
kemampuannya dalam menyerap tenaga kerja sampai 107 juta. Di tahun 2012 juga data terkait jumlah pengusaha di Indonesia menunjukkan sebanyak 56.539.560 unit dengan mayoritas pengusaha berasal dari sektor UMKM yaitu sebesar 99,99 persen.

Selanjutnya berdasarkan data dari Kementerian Koperasi dan Usaha Kecil dan Menengah yang diolah dari data BPS menunjukkan bahwa sampai tahun 2018, sektor UMKM di Indonesia tercatat sebanyak 64.194.057 unit atau mencapai 99,9 persen dari keseluruhan sektor usaha yang ada di Indonesia. UMKM juga mampu membuktikan kontribusinya dengan menyerap tenaga kerja sebesar 116.978.631 atau sekitar 97 persen dari jumlah tenaga kerja di sektor usaha.

Menurut Kogoya (2020) terdapat 3 peranan penting UMKM dalam kehidupan masyarakat Indonesia yaitu: (1) mengentaskan kemiskinan yaitu UMKM berperan penting dalam menciptakan lapangan pekerjaan. (2) meratakan tingkat perekonomian masyarakat. UMKM tumbuh dan berkembang di daerah-daerah, termasuk daerah yang jauh dari ekspansi industri skala besar. (3) Berkontribusi pada devisa negara. Saat ini, UMKM Indonesia mengalamai kemajuan sehingga dapat menembus pangsa pasar internasional. Data dari Kementerian Koperasi dan UKM di tahun 2017, kontribusi dari para pengusaha UMKM terhadap devisa negara mengalami peningkatan dibandingkan tahun 2016 yaitu mencapai Rp88,45 miliar.

UMKM di Indonesia telah terbukti mampu bertahan pada krisis multidimensi tahun 1998, krisis global tahun 2008, dan mampu menyerap banyak tenaga kerja, serta berperan strategis menjaga stabilitas ekonomi regional maupun nasional. Besarnya peran UMKM dalam pengembangan dan kemanjuan ekonomi daerah suatu wilayah dikarenakan sektor UMKM mampu menyerap banyak sumber daya yang apabila di eksploitasi secara bijak dan proporsional dapat mendorong pengembangan wilayah dan perluasan kesempatan kerja yang signifikan. Berkembangkan perekonomian daerah akan menaikkan perekonomian nasional.

Program pemberdayaan UMKM sangat sesuai jika dikaitkan dengan konsep sistem Ekonomi Kerakyatan yang memiliki ciri utama yaitu keikutsertaan rakyat dalam kepemilikan modal usaha, proses produksi dan merasakan manfaatnya. Salah satu strategi yang dapat digunakan untuk memperkuat perekonomian nasional yaitu dengan memberikan pembinaan kapada pengusaha UMKM dalam menjalankan usaha (Agusalim, Karim, \& Saefuddin, 2014).

Pemberdayaan UMKM menjadi strategi penting bagi keberhasilan program pembangunan nasional dengan berlandasan sistem Ekonomi Kerakyatan yang demokratis, berkelanjutan dan berkeadilan sosial. Strategi tersebut diharapkan dapat mewujudkan perekonomian yang lebih merata, adil, berdaya saing dan memiliki keunggulan kompetitif dalam persaingan global, berwawasan keberlanjutan yaitu dengan mengeksploitasi sumber daya alam dan lingkungan hidup secara bijak dan proporsional, keikutsertaan masyarakat yang lebih aktif dan desentralisasi dalam pembangunan untuk meningkatkan kapasitas dan memaksimalkan potensi yang dimiliki daerah (Kader, 2018).

Upaya pemberdayaan UMKM merupakan upaya strategis dalam menciptakan daya saing, menciptakan keunggulan kompetitif dan ketahanan perekonomian nasional serta mampu mewujudkan sistem Ekonomi Kerakyatan. Potensi UMKM yang merupakan usaha dinamis dan fleksibel memiliki daya responsif dan adaptasi yang tinggi terhadap perubahan iklim ekonomi, teknologi dan pangsa pasar. Dengan demikian UMKM diharapkan mampu lebih berperan dalam mengatasi adanya kesenjangan tingkat pendapatam, pemenuhan kebutuhan hidup masyarakat, dan meningkatkan lajunya roda perekonomian daerah serta nasional. 


\section{SIMPULAN DAN SARAN}

Sistem Ekonomi Kerakyatan adalah sistem perekonomian yang didasarkan pada basis kedaulatan rakyat. Sistem Ekonomi Kerakyatan berasaskan pada kekeluargaan, demokratis dan berkeadilan mendorong rakyat Indonesia untuk ikut serta dalam kepemilikan modal dan sebagai pengendali perekonomian. Berlakunya otonomi daerah saat ini, maka konsep sistem Ekonomi Kerakyatan untuk memberdayakan UMKM harus diwujudkan dalam bentuk program usaha yang berbasis ekonomi daerah dengan tingkat kemandirian yang tinggi. Pemberdayaan UMKM yang berdasar pada sistem Ekonomi Kerakyatan sudah harus menjadi prioritas dalam meningkatkan pembangunan nasional, karena terbukti sektor UMKM mampu bertahan pada setiap perubahan iklim ekonomi termasuk dalam kondisi krisis ekonomi. Pemberdayaan UMKM dapat terlaksana apabila terdapat kerjasama yang baik antara pemerintah, masyarakat, pengusaha UMKM, stakeholder dan pihak-pihak swasta. Dengan landasan semangat ideologi sistem Ekonomi Kerakyatan dari beberapa pihak tersebut, maka akan meningkatkan perekonomian daerah yang secara langsung akan memiliki dampak pada peningkatan perekonomian nasional.

Peran pemerintah daerah maupun pemerintah pusat dalam membuat kebijakan terkait pemberdayaan UMKM perlu memperhatikan lagi prinsip-prinsip sistem ekonomi yang berlaku. Dengan berkembangnya UMKM Indonesia, maka dapat menjadi bukti bahwa sistem Ekonomi Kerakyatan sudah berjalan sesuai dengan prinsip dan tujuan yang tercermin dalam UUD RI tahun 1945 Pasal 33.

\section{REFERENSI}

Agusalim, Lestari, Karim, Muhammad, \& Saefuddin, Asep. (2014). Rekonstruksi Ekonomi Pancasila Sebagai Perwujudan Keberlanjutan Pembangunan Nasional. Jurnal Kesejahteraan Sosial, 1(01), 39-53. https://doi.org/10.31326/jks.v1i01.138

Bhudianto, Wahyu. (2012). Sistem Ekonomi Kerakyatan dalam Globalisasi Perekonomian. Transformasi, 14(22), 1-9.

Firmansyah, Arif. (2012). Penafsiran Pasal 33 UUD1945 dalam Membangun Perekonomian Di Indonesia. Syiar Hukum: Jurnal Ilmu Hukum, 13(1), 264-288. https://doi.org/https://doi.org/10.29313/sh.v14i1.1451

Hapsari, Dwi Ratna Indri. (2019). Hukum dalam Mendorong Dinamika Pembangunan Perekonomian Nasional ditinjau dari Prinsip Ekonomi Kerakyatan. Legality, 26(2), 238-251.

Hoesein, Zainal Arifin. (2016). Peran Negara Dalam Pengembangan Sistem Ekonomi Kerakyatan menurut UUD 1945. Jurnal Hukum IUS QUIA IUSTUM, 23(3), 503-528. https://doi.org/10.20885/iustum.vol23.iss3.art8

Kader, Mukhtar Abdul. (2018). Peran Ukm Dan Koperasi Dalam Mewujudkan Ekonomi Kerakyatan Di Indonesia. JURISMA: Jurnal Riset Bisnis \& Manajemen, 8(1), 15-32. https://doi.org/10.34010/jurisma.v8i1.995

Kogoya, Rudi. (2020). Kekuatan Ekonomi Rakyat dan Pengaruhnya terhadap Kemajuan Indonesia. Global \& Policy, 8(2), 78-88.

Malau, Natalia Artha. (2016). Ekonomi Kerakyatan Sebagai Paradigma Dan Strategi Baru Dalam Pembangunan Ekonomi Indonesia. Jurnal Ilmiah "Research Sainis," 2(1), 1-8.

Marzuki, Alie. (2015). Indikator Ekonomi. Yogyakarta: UPP STIM YKPN.

Mubyarto. (2014). Ekonomi Karakyatan. Retrieved from http://library1.nida.ac.th/termpaper6/sd/2554/19755.pdf

Retnowati, Tutiek, Boediningsih, Widyawati, \& Afdol. (2018). Kebijakan Pengembangan UMKM Berbasis Ekonomi Kerakyatan di Jawa Timur. Prosiding Seminar Nasional Hasil Penelitian Dan Pengabdian Kepada Masyarakat III, 3(September), 316-322. Retrieved from https://www.google.com/url?sa=t\&rct=j\&q=\&esrc=s\&source=web\&cd=\&cad=rja\&uact=8\&ved=2ahUKE wiB2uuMyMjsAhXjH7cAHQlwCVIQFjAEegQIBBAC\&url=http\%3A\%2F\%2Fprosiding.unirow.ac.id\%2 Findex.php $\% 2$ FSNasPPM $\% 2$ Farticle $\% 2$ Fdownload\%2F191\%2F196\%2F\&usg=AOvVaw2N7sRbJ2CCSE TSHsnEa

Sadikin, Achmad. (2011). Membangun Ekonomi Kerakyatan dalam Kerangka Paradigma Pembangunan 
Kemandirian Lokal. Majalah Ilmiah Ekonomika, 11(4), 146-154.

Santosa, Agus. (2020). Pengembangan Ekonomi Kreatif Industri Kecil Menengah Kota Serang Di Masa Pandemi Covid-19. Syntax Literate: Jurnal Ilmiah Indonesia, 5(11), 1257-1272.

Suryati, Desi, \& Salkiah, Baiq. (2019). Analisis Program Pemberdayaan Ekonomi Kerakyatan Pada UMKM Di Kota Mataram. Media Bina Ilmiah, 13(12), 1823. https://doi.org/10.33758/mbi.v13i12.266

Swasono, Sri Edi. (2020). Ekonomi Rakyat dan Koperasi. Webinar Memperingati Hari Koperasi 12 Juli 2020 , $1-9$.

Thurmond, Veronica A. (2001). The Point of triangulation. Journal of Nursing Scholarship, 33(3), $253-258$. https://doi.org/10.1111/j.1547-5069.2001.00253.x 